\title{
Pico- and ultraplankton Sargasso Sea communities: variability and comparative distributions of Synechococcus spp. and algae*
}

\author{
Hilary E. Glover ${ }^{1}$, Barbara B. Prézelin ${ }^{2}$, Lisa Campbell ${ }^{3}$, Michael Wyman ${ }^{4}$ \\ ${ }^{1}$ Bigelow Laboratory for Ocean Sciences, W. Boothbay Harbor, Maine 04575, USA \\ ${ }^{2}$ Department of Biological Sciences and Marine Science Institute, University of California, Santa Barbara, California 93106, \\ USA \\ ${ }^{3}$ Department of Oceanography, University of Hawaii, Honolulu, Hawaii 96822, USA \\ ${ }^{4}$ Department of Biological Sciences, University of Warwick, Coventry, United Kingdom
}

\begin{abstract}
Ultraplankton $(0.2$ to $5 \mu \mathrm{m}$ ) provided $>88 \%$ of euphotic layer chlorophyll (Chl) at 2 Sargasso Sea stations in July/August 1986. Communities were further characterized to quantify the separate abundances of phycoerythrin-fluorescing cyanobacteria Synechococcus spp. and Chl-fluorescing algae in 0.2 to $0.6,0.6$ to 1 and 1 to $5 \mu \mathrm{m}$ size fractions. Throughout the water-column at both stations, the majority of Synechococcus cells were consistently found in the 0.6 to $1 \mu \mathrm{m}$ fraction; the Sargasso Sea WH7803 serogroup was not a dominant component of Synechococcus populations at any depth. Highest numbers of Synechococcus cells were always in the surface isothermal layer, where they accounted for $>95 \%$ of all ultraphytoplankton cells. At the base of the euphotic layer total numbers of photoautotrophs were low, but numbers of algae increased. The varying distribution of the 2 ultraphytoplankton components with depth was also reflected in their separate contributions to Chl concentrations, and algae were the main contributors to $\mathrm{Chl}$ maxima at 1 to $3 \% \mathrm{I}_{0}$. Above this depth, a pigment maximum in phycoerythrin (PE) $1^{-1}$ occurred at the nitracline, coincident with a peak in primary productivity. PE maxima were due to an increase in PE content of Synechococcus cells and not to an increase in their abundance. The 2 stations did however exhibit significant differences. High surface productivity at Stn 1 was supported by nanomolar changes in nitrate concentrations, which selectively and rapidly induced a Synechococcus bloom. In contrast, the water-column characteristics of Stn 2 were relatively stable, Synechococcus spp. were less abundant throughout the water-column, while algae were twice as abundant at the Chl maximum and $0.5 \%$ light level, where most were of picoplankton size ( 79 to $89 \%$ of algae were in $<1 \mu \mathrm{m}$ fractions). Data suggest that there is a considerable degree of variability in the abundance, composition, and productivity of stratified oceanic ultraphytoplankton communities.
\end{abstract}

\section{INTRODUCTION}

During the last decade, increasing efforts in biological oceanography have been focused on defining and quantifying the microbial components of oceanic rate processes, particularly as they affect the cycling of carbon and nitrogen. Renewed interest in oceanic phytoplankton and primary productivity estimates has been largely stimulated by new information on the predominance and activity of ultra- $(<3 \mu \mathrm{m})$ and picophytoplankters $(<1 \mu \mathrm{m})$. The ecological success of

\footnotetext{
- Bigelow Laboratory for Ocean Sciences Contribution No. 87018
}

these in oceanic regions has been partly attributed to the increased efficiency of light-harvesting and nutrient uptake conferred by their small cell size (cf. Fogg 1986, Kirk 1986, Raven 1986) and their negligible sinking rates (Takahashi \& Bienfang 1983). Revised higher estimates of oceanic primary productivity (e.g. Laws et al. 1987, Marra \& Heinemann 1987) have a direct impact upon developing models of biogeochemical cycling of carbon and nitrogen in the upper ocean, where dynamics are driven by synergistic interactions between ultraplankton-size photoautotrophs, chemoautotrophs, methanotrophs, heterotrophic bacteria and their protozooplankton grazers (cf. reviews by Fogg 1986, Platt \& Li 1986, Stockner \& Antia 1986). 
More recently, it has become apparent that ultraphytoplankton contains both cyanobacteria and algae. These 2 photosynthetic components can be distinguished in mixed communities and enumerated by direct count epifluorescence microscopy, since red-pigmented cyanobacterial cells have a dominant phycoerythrin (PE) fluorescence emission, while all algal species have a predominant Chl fluorescence emission (Glover 1985). While the contribution of marine cyanobacterial populations of Synechococcus spp. to primary production has received considerable attention (see reviews by Glover 1985, Waterbury at al. 1986), direct estimates of both the biomass and photosynthetic activity of similarly-sized algae within the same water mass had never been attempted.

During a cruise to the Sargasso Sea in summer 1986, we used 2 recently developed field techniques to measure nanomolar nitrate concentrations in surface waters and Synechococcus PE concentrations throughout the water-column. We also compared the abundance of Synechococcus spp. to that of algae in different size-fractions and estimated the separate contributions of these 2 phytoplankton components to the total standing crop of Chl and primary productivity at several depths. Measurements and experiments were also designed to define possible differences in adaptive responses employed by Synechococcus spp. and algal ultraplankters $(<5, \mathrm{~m})$ to cope with variations in light and nutrient flux that might explain any distributional differences. This manuscript describes the temporal and spatial variations that we observed in PE and Chl concentrations and the numerical abundance of Synechococcus spp. and algae in ultra $-(<5 \mu \mathrm{m})$ and pico- $(<1 \mu \mathrm{m})$ phytoplankton communities.

\section{MATERIALS AND METHODS}

This study was conducted in the Sargasso Sea (Fig. 1) during the summer of 1986 from the RV 'Endeavor' (Cruise EN-146). Stn 1 was $140 \mathrm{~km}$ east of Bermuda $\left(32^{\circ} 42^{\prime} \mathrm{N}, 63^{\circ} 01^{\prime} \mathrm{W}\right)$ and was occupied from 20 to 28 July. Stn 2 was $165 \mathrm{~km}$ NNW of Bermuda $\left(33^{\circ} 42^{\prime} \mathrm{N}\right.$, $65^{\circ} 22^{\prime} \mathrm{W}$ ) and was occupied from 2 to 9 August.

Physical/chemical measurements and sample collection. The research vessel received daily charts of sea surface temperature derived from NOAA satellite images (AVHRR) and the position of the Gulf Stream and cold-core eddies in Fig. 1 were taken from the NOAA/National Weather Service analysis on 18 July. Subsequent thermal maps indicated that these features did not change significantly throughout the cruise.

A submersible pumping system $(180 \mathrm{~m})$ was constructed to collect discrete samples, while providing simultaneous continuous vertical profiles of tempera-

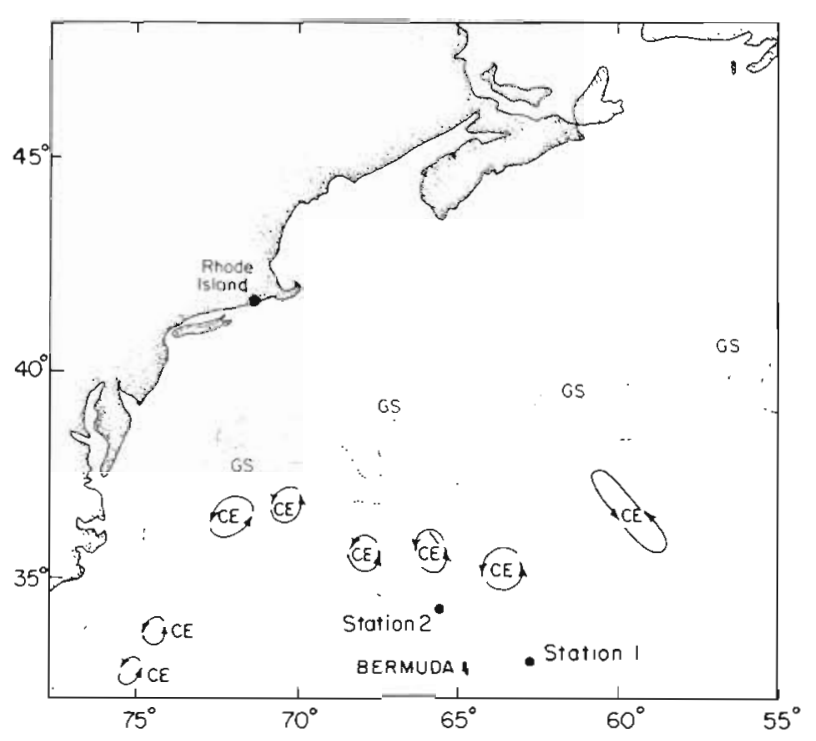

Fig. 1. Locations of 2 stations in the Sargasso Sea during RV 'Endeavor' Cruise EN-146, 17 July to 11 August 1986. Position. of Gulf Stream (GS) and cold-core eddies (CE) were taken from NOAA/National Weather Service analyses on 18 July

ture, in vivo Chl fluorescence and quantum irradiance (Biospherical design) as a function of depth. One modification over the prior system (Prézelin et al. 1987) was the use of an internal hose diameter of $5 \mathrm{~cm}$, intentionally enlarged to minimize shear effects on phytoplankton populations, and pumping was demonstrated to have no effect on either phytoplankton biomass or photosynthetic activity, when compared to replicate samples collected with GOFLO bottles. The flow rate was ca $113 \mathrm{l}^{-1} \mathrm{~min}^{-1}$, with a 3 min transit time from intake to outlet. Pump effluent was directed through an adapted Turner fluorometer to measure in vivo $\mathrm{Chl}$ fluorescence. Analog data from the fluorometer, temperature and depth probes, in situ irradiance and daily incident irradiance, (quantum sensor, Biospherical Instruments) were recorded on strip charts.

Samples from discrete depths were collected from the fluorometer outflow into $125 \mathrm{ml}$ polyethylene bottles and frozen for subsequent onshore analysis of nitrate concentrations. Nitrate in the upper $60 \mathrm{~m}$ was measured using a chemiluminescent technique (precision of $\pm 2 \mathrm{nM}$; Garside 1982), and at greater depths by the standard colorimetric method (precision of \pm 80 $\mathrm{nM}$; Strickland \& Parsons 1972). Discrete samples were collected directly from the pump effluent into darkened 201 polypropylene carboys, that were immediately transported into the shipboard laboratory for analysis. All apparatus used for the collection and incubation of water samples was cleaned by the procedure of Fitzwater et al. (1982). To recycle, the vessels were rinsed with $0.25 \mathrm{~N} \mathrm{HCl}$ followed by deionized water.

Cell enumeration of photoautotrophs. Numbers of 
Chl-fluorescing algae and PE-fluorescing Synechococcus cells were determined by epifluorescence microscopy in 3 size-fractions of unpreserved samples separated by differential filtration (Glover et al. 1986). A minimum of 100 cells were counted and standard deviations were 10 to $25 \%$ of the mean count of several microscope fields for 1 to $5 \mu \mathrm{m}$ and 0.6 to $1 \mu \mathrm{m}$ assemblages. Standard deviations were however routinely $>25 \%$ for 0.2 to $0.6 \mu \mathrm{m}$ assemblages, principally due to the very low cell counts in this size range. The percentage of total phytoplankton cells represented by Synechococcus spp. in each size range is shown in Table 1. Duplicate samples were preserved in buffered formalin and stored in the dark at $4^{\circ} \mathrm{C}$ for onshore enumeration of 2 Synechococcus serogroups by immunofluorescence labelling (Campbell \& Carpenter 1987). Antiserum produced against the Sargasso Sea isolate WH7803 was cross-absorbed with cells of the coastal isolate WH8016, and vice versa, before use.

Cell enumeration of bacteria. Numbers of bacteria were also determined in preserved samples, using the acridine orange direct counting method of Hobbie et al. (1977). A minimum of 100 cells were counted and standard deviations were 3 to $21 \%$ of the mean count of several microscope fields.

Phytoplankton pigment concentrations. Duplicate samples were filtered to determine particulate $\mathrm{Chl}$ concentrations, the volume $(50 \mathrm{ml}$ to $1 \mathrm{l})$ depending on the in vivo $\mathrm{Chl}$ fluorescence signal from the pump profile and the filter pore size. Each sample was divided into 4 portions, which were filtered through separate Nuclepore filters of $5,1,0.6$ and $0.2 \mu \mathrm{m}$ pore sizes and filtrates were discarded. Methods for filtration and extraction are described in Glover et al. (1986). Chl concentrations were determined directly for $>5 \mu \mathrm{m}$ communities and by mathematical subtraction for 1 to $5,0.6$ to 1 and 0.2 to $0.6 \mu \mathrm{m}$ fractions. Standard errors were routinely $<10 \%$ of the mean. Cell-specific Chl concentrations in pure 0.6 to $1 \mu \mathrm{m}$ Synechococcus populations (92 to $100 \%$ of all autofluorescent cells; Table 1), were used in conjunction with cell numbers in the 1 to 5 and 0.2 to $0.6 \mu \mathrm{m}$ fractions, to estimate Synechococcus $\mathrm{Chl}$ in these other size ranges. The quantity of algal $\mathrm{Chl}$ in 1 to 5 and 0.2 to $0.6 \mu \mathrm{m}$ fractions could then be calculated by subtracting the amount of Synechococcus Chl from the total concentration in each size category. It was only at the $\mathrm{Chl} \max$ and the $0.5 \%$ light depth that the 0.6 to $1 \mu \mathrm{m}$ fraction could not be considered a pure population of Synechococcus, as they routinely represented $<50 \%$ of all the autofluorescing cells in this size range (Table 1). At these depths, we could only estimate cellular Chl concentrations of Synechococcus spp. by proportion, using relative numbers of Synechococcus:algal cells within the 0.6 to $1 \mu \mathrm{m}$ fraction. Synechococcus Chl may therefore have been overestimated at the base of the euphotic layer, as algae in this size fraction would probably contain more Chl per cell than Synechococcus spp. (see Table II of Glover et al. 1987), since the former were probably larger and $\mathrm{Chl}$ is one of their primary light-harvesting pigments.

PE concentrations were determined at sea, using the in vivo fluorescence method of Wyman \& Carr (1988), which is based on the ability of glycerol to uncouple energy transfer between PE and phycocyanin (Wyman et al. 1985). Samples (1 1) were filtered through Nuclepore filters of $0.6 \mu \mathrm{m}$ pore size to collect Synechococcus cells. Cells were resuspended in $5 \mathrm{ml}$ of $50 \%$ glycerol, excited at $520 \mathrm{~nm}$ and PE fluorescence emission was determined at $570 \mathrm{~nm}$ in an adapted Turner fluorome-

Table 1. Percentage of autofluorescing phytoplankton cells represented by PE-rich Synechococcus spp. within 3 size fractions at various depths in the euphotic zone. Mean value $(\bar{x})$, and range (in brackets) is provided for samples collected from different pump casts over $5 \mathrm{~d}$

\begin{tabular}{|c|c|c|c|c|c|c|c|c|c|}
\hline \multicolumn{2}{|c|}{$\begin{array}{l}\text { Light depth } \\
\qquad\left(\begin{array}{ll}\% & I_{0}\end{array}\right)\end{array}$} & $\frac{1-5 \mu \mathrm{m}}{\overline{\mathrm{x}}}$ & $\begin{array}{l}\text { Station } 1 \\
0.6-1 \mu \mathrm{m} \\
\overline{\mathrm{x}}\end{array}$ & $\begin{array}{l}0.2-0.6 \mu \mathrm{m} \\
\bar{x}\end{array}$ & \multicolumn{2}{|c|}{$\begin{array}{l}\text { Light depth } \\
\quad\left(\begin{array}{ll}\% & I_{o}\end{array}\right)\end{array}$} & $\frac{1-5 \mu \mathrm{m}}{\overline{\mathrm{x}}}$ & $\begin{array}{l}\text { Station } 2 \\
0.6-1 \mu \mathrm{m} \\
\overline{\mathrm{x}}\end{array}$ & $\begin{array}{l}0.2-0.6 \mu \mathrm{m} \\
\overline{\mathrm{x}}\end{array}$ \\
\hline & 90 & $93(91-96)$ & $100(99-100)$ & $98(90-100)$ & & 90 & $91(81-95)$ & $99(98-100)$ & $99(98-100)$ \\
\hline \multirow{7}{*}{$P E_{\max }$} & 64 & $91(89-94)$ & $99(99-100)$ & $95(79-100)$ & & - & - & - & - \\
\hline & - & - & - & - & & 40 & $89(87-92)$ & $99(99-100)$ & $99(96-100)$ \\
\hline & 34 & $91(81-97)$ & $99(98-100)$ & $98(92-100)$ & & - & - & - & - \\
\hline & 26 & $71(44-86)$ & $98(98-100)$ & $97(88-100)$ & & 26 & $87(76-94)$ & $98(97-100)$ & $98(92-100)$ \\
\hline & - & - & - & - & & 19 & $72(54-87)$ & $98(96-100)$ & $98(94-100)$ \\
\hline & 14 & $80(77-85)$ & $98(97-100)$ & $92(77-100)$ & & - & - & - & - \\
\hline & - & - & - & - & & 9 & $69(64-78)$ & $95(91-98)$ & $91(81-97)$ \\
\hline \multirow[t]{2}{*}{$P E_{\max }$} & 6 & $77(70-93)$ & $92(87-94)$ & $50 \quad(7-100)$ & & - & - & - & - \\
\hline & - & - & - & - & $P E_{\max }$ & 4 & $76(65-83)$ & $92(85-97)$ & $74(44-100)$ \\
\hline \multirow[t]{3}{*}{$\mathrm{Chl}_{\max }$} & 3 & $44(19-68)$ & $62(34-81)$ & $34(0-82)$ & & - & - & - & - \\
\hline & - & - & - & - & $\mathrm{Chl}_{\max }$ & 1.5 & $31(23-40)$ & $35(16-45)$ & $54(32-100)$ \\
\hline & 0.5 & $40(19-78)$ & $66(42-77)$ & $38(0-100)$ & & 0.5 & $25(13-33)$ & $39(9-63)$ & $45(0-86)$ \\
\hline
\end{tabular}


ter, calibrated with both whole cells and isolated phycobilisomes from the Sargasso Sea Synechococcus clone, WH7803. Since the washing procedure did not remove all the cells from the filter, cell numbers were determined in the glycerol suspension and data were corrected accordingly.

Photosynthesis measurements. Diurnal measurements of photosynthesis-irradiance (P-I) relations were conducted on whole communities collected from 8 depths at dawn, midday and dusk. Values reported here are for midday values only. Procedures for filtration, washing and determining rates of ${ }^{14} \mathrm{C}$ fixation are described by Prézelin et al. (1986). Photosynthetic parameters were derived from non-linear curve fits for the P-I data (Prézelin et al. 1986). Independent measurements of $P_{\max }$ indicated that one standard deviation was routinely $<15 \%$ of the mean value.

In situ rates of daily primary production were determined for whole communities from 8 depths. ${ }^{14} \mathrm{C}$-bicarbonate was added to duplicate $230 \mathrm{ml}$ samples in polycarbonate bottles $\left(1.3\right.$ to $1.5 \mu \mathrm{Ci} \mathrm{m} l^{-1}$ final concentration). At dawn, bottles were suspended at each depth using an in situ line and float. Bottles were retrieved at dusk (12 h incubation) and $50 \mathrm{ml}$ portions were filtered through Nuclepore filters of $0.2 \mu \mathrm{m}$ pore size. Additional samples from each depth were also filtered immediately after the addition of ${ }^{14} \mathrm{C}$-bicarbonate, for zero time controls. One standard deviation ranged from 2 to $16 \%$ of the mean value (with one exception of $30 \%$ ). Procedures for filtration, washing, and determining photosynthetic rates are provided in Glover et al. (1986).

\section{RESULTS}

Both stations were stratified with pigment maxima below the thermocline and more than $88 \%$ of the integrated standing crop of Chl was found in ultraplankton $(0.2$ to $5 \mu \mathrm{m})$. Vertical profiles of light availability as well as the abundance and composition of ultraphytoplankton assemblages were different at the 2 stations (Figs. 2 to 5). In addition, the water-column characteristics at Stn 2 were relatively stable over the monitoring period, while temporal changes occurred in the surface isothermal layer at Stn 1.

\section{Similarities between stations}

Both stations exhibited a number of similar features: An in vivo PE glycerol-uncoupled fluorescence maximum occurred on the $21.5^{\circ} \mathrm{C}$ isotherm at 3.7 to $6.5 \%$ $I_{0}$, in the upper part of the nitracline (Figs. 2 and 3 ) and coincident with a maximum in midday photosynthetic capacity (Table 2). Below the PE maximum there was an in vivo $\mathrm{Chl}$ fluorescence maximum, which followed the $21^{\circ} \mathrm{C}$ isotherm (Fig. 2) at the base of the nitracline $\left(>10 \mu M \mathrm{NO}_{3}\right)$. Extracted $\mathrm{Chl}$ concentrations showed similar depth distributions (Fig. 3), such that the Chl fluorescence:biomass ratio was constant. One excep-

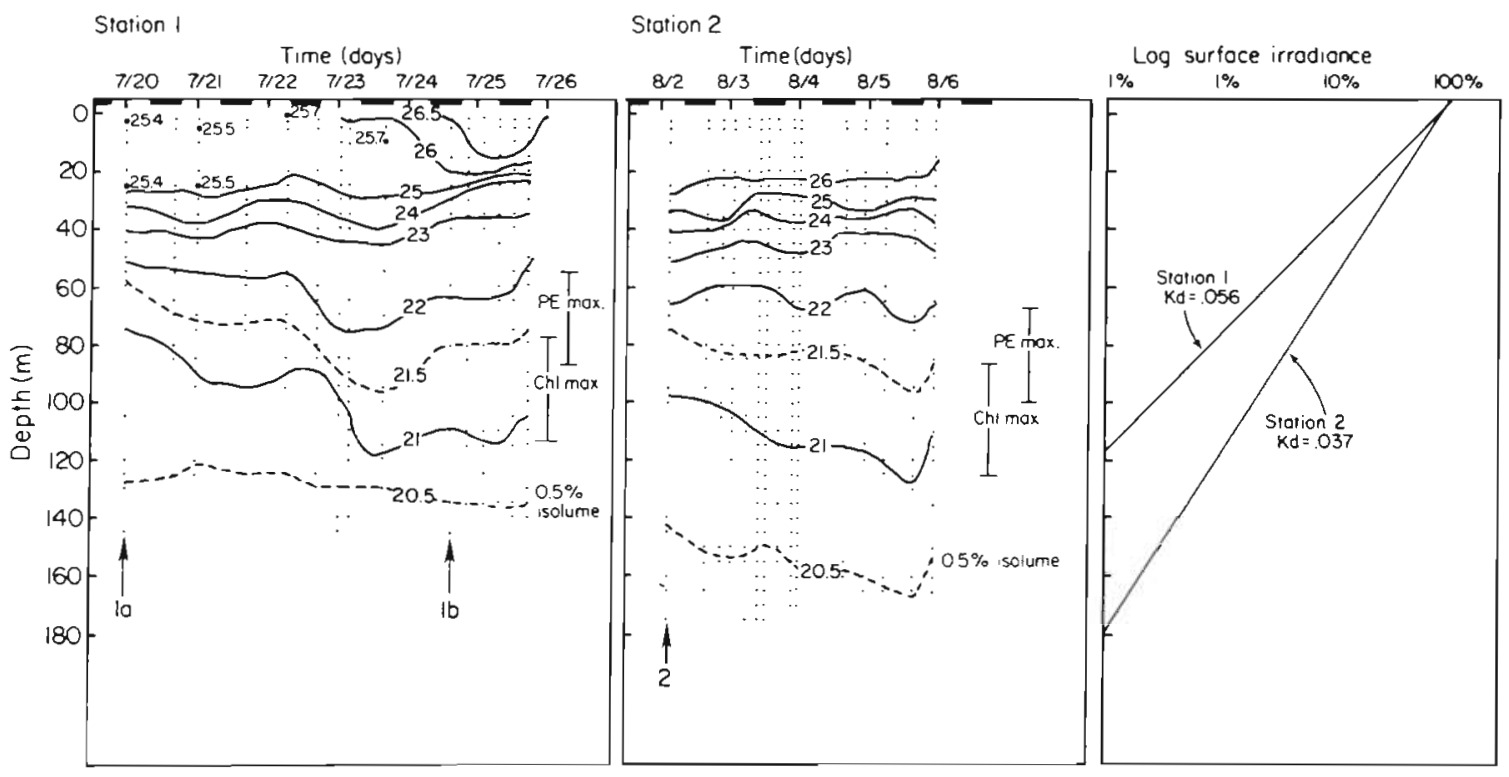

Fig. 2. Depth profiles of temperature and irradiance at the 2 stations. Temperature structure and position of in vivo Chl fluorescence maximum were derived from continuous vertical pump profiles taken at various times (.). Attenuation coefficients $(\mathrm{Kd})$ for each station are mean values obtained from several profiles of downwelling irradiance taken over similar time frames. Position of PE maximum was derived from discrete analyses of samples from the pump outflow. Arrows $(1 \mathrm{a}, 1 \mathrm{~b}$ and 2$)$ indicate the times of pump casts for collection of data presented in Figs. 3, 5,6, 7 and 9 
Station 1
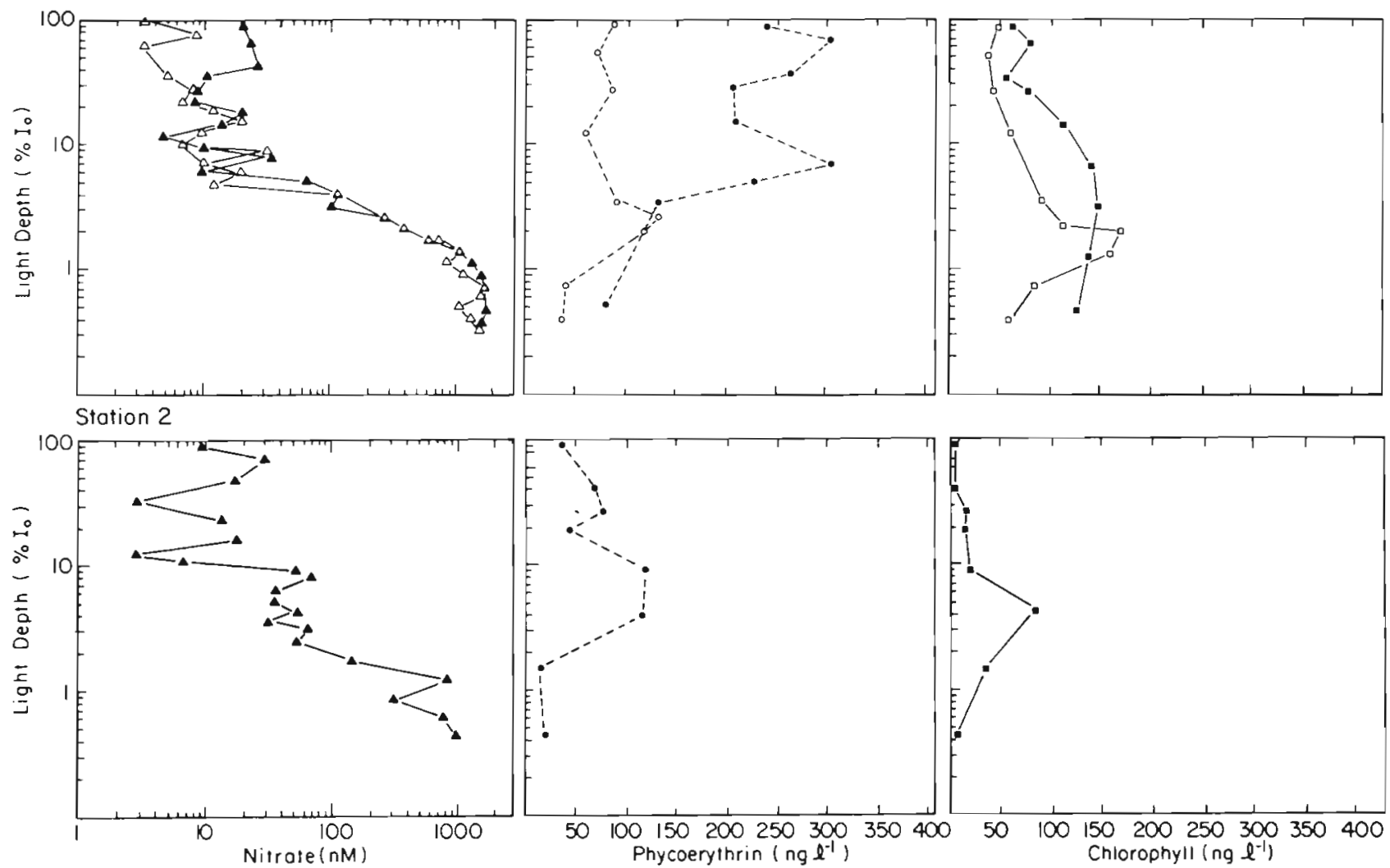

Fig. 3. Concentrations of nitrate (left graphs), phycoerythrin (middle graphs) and chlorophyll (right graphs) in water samples from different depths in the euphotic zones of the 2 stations. Temporal changes at Stn 1 are seen by the differences in depth profiles between 20 July (solio symbols) and 25 July (open symbols). Data for Stn 2 are from 2 August

Table 2. Photosynthetic rates and characteristics of whole phytoplankton communities (>0.2 $\mu \mathrm{m})$

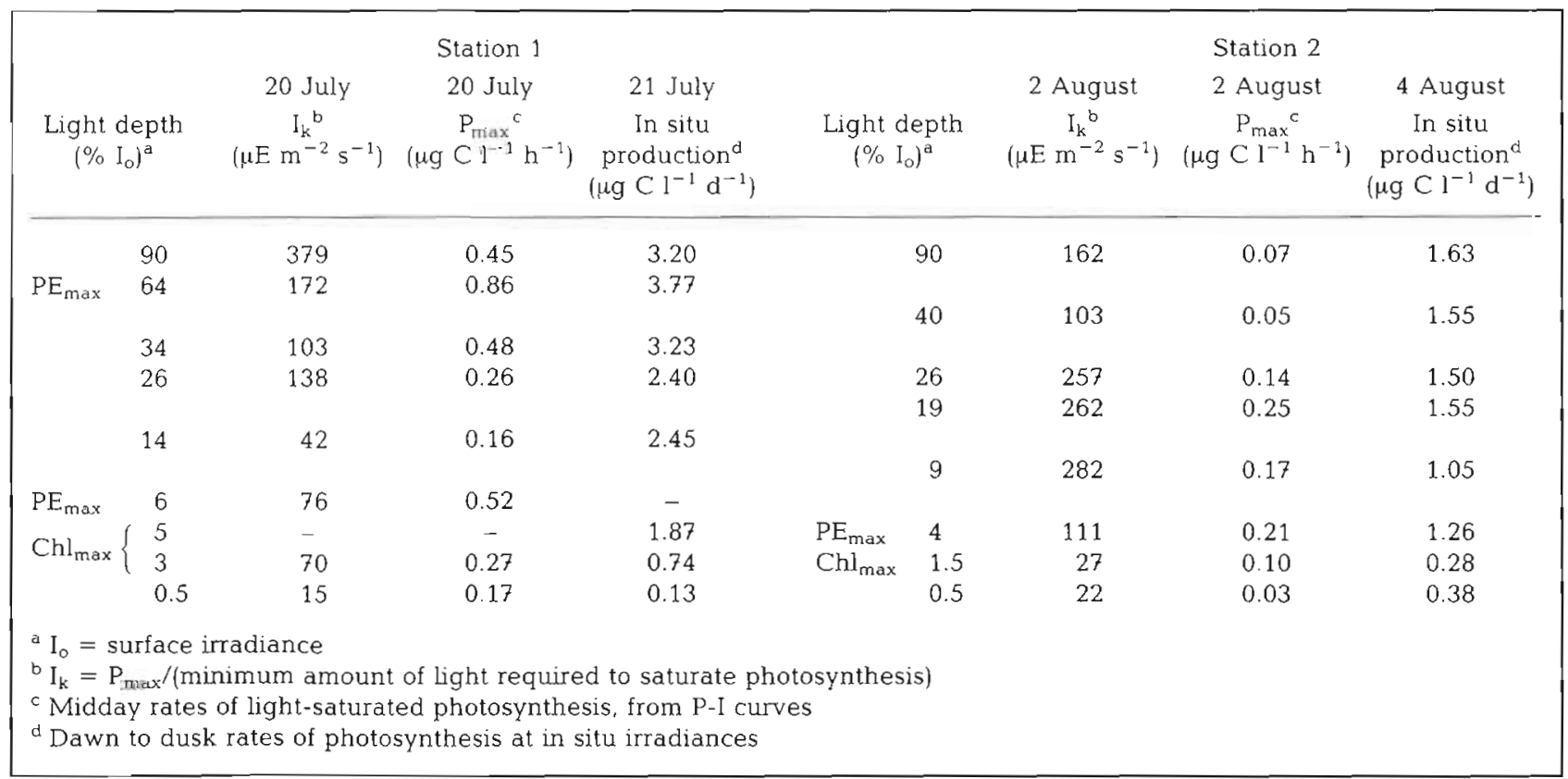


tion occurred on 2 August at Stn 2, when maximum concentrations of $\mathrm{PE}$ and $\mathrm{Chl}$ per liter were coincident.

At both stations, Synechococcus spp. were most abundant in the surface isothermal layer (Fig. 4), but they represented less than $8 \%$ of the total number of prokaryotes, as bacterial abundance was 198 to $283 \times 10^{6}$ cells $1^{-1}$ above the thermocline at both sta- tions (Fig. 5). Depth distribution studies indicated that high cell numbers of Synechococcus occurred in the mid to upper portion of the euphotic zone $\left(>10 \% \mathrm{I}_{0}\right)$ above pigment maxima and the maximum abundance of algal ultraphytoplankters (Fig. 5). Since Synechococcus cell numbers were lower at the PE maximum than those in the surface isothermal layer
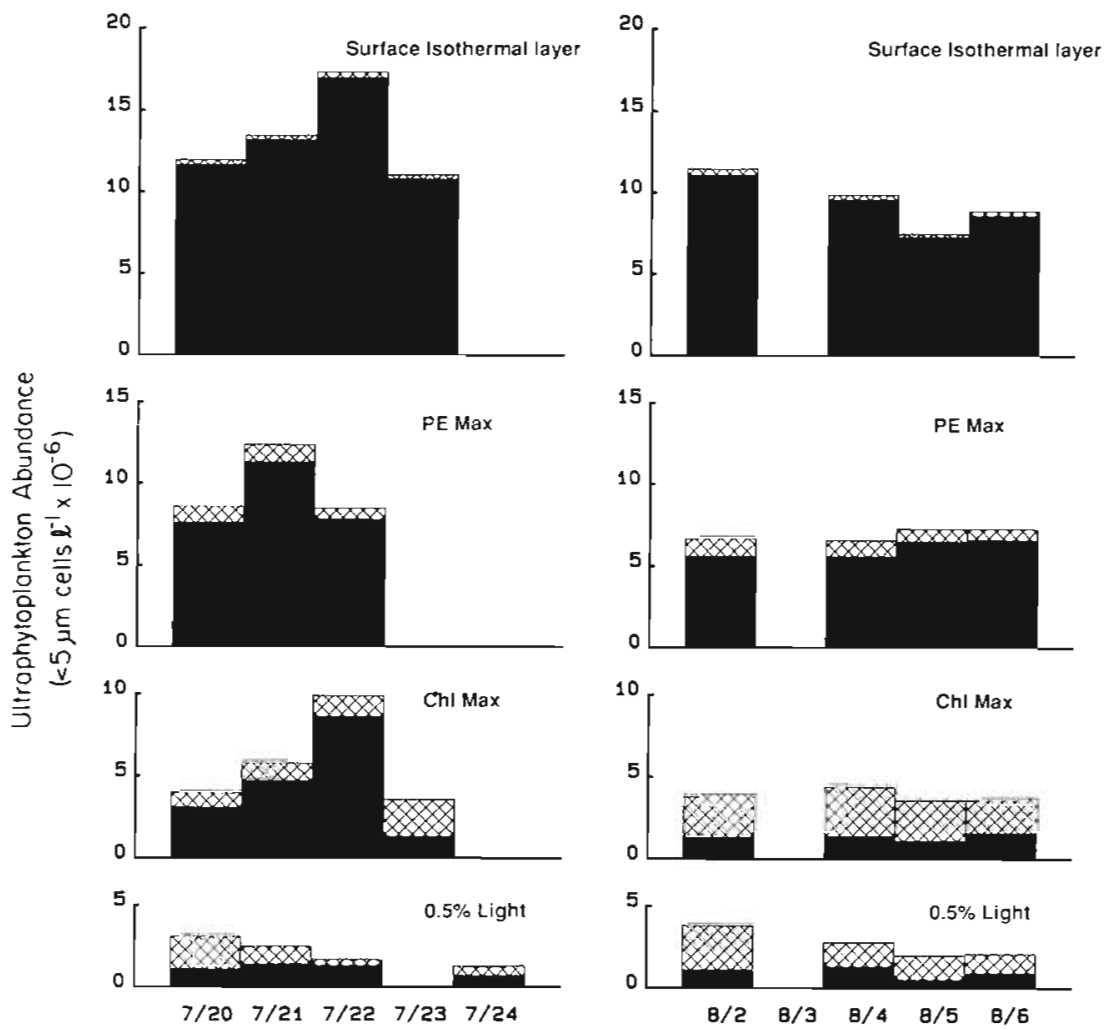

Fig. 4. Variations in the numerical abundance of Synechococcus spp. (black bars) and algae (cross-hatched bars) in ultraplankton assemblages at 4 locations in the water-column over the course of the monitoring periods at Stn 1 (left graph) and Stn 2 (right graph). As pigment maxima were broadly distributed as a function of depth, data presented here from the PE and Chl maxima represent time course changes in phytoplankton communities from the $21.5^{\circ} \mathrm{C}$ and $21^{\circ} \mathrm{C}$ isotherms, respectively

Station 1

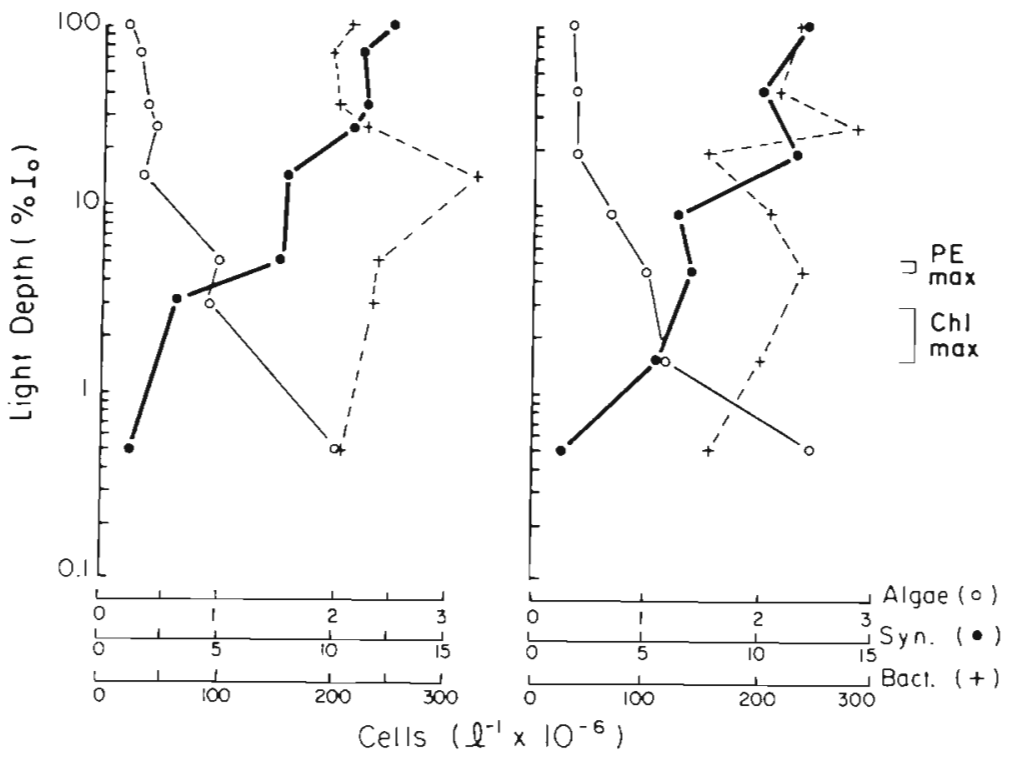

Fig. 5. Depth distribution of Synechococcus spp. $(\bullet)$ algae (o) and bacteria ( + ) in ultraplankton assemblages $(0.2$ to $5 \mu \mathrm{m}$ ) at Stn 1 on 20 July (left graph) and Stn 2 on 2 August (right graph). Depths of the Chl and PE maxima are indicated to the right 
(Figs. 4 and 5), the relatively higher PE concentrations at the nitracline maximum (Fig. 3) were due to an increase in cellular PE content. Fig. 6 shows the increase in Synechococcus PE cell ${ }^{-1}$ below the $10 \%$ isolume at both stations. Synechococcus spp. accounted for $>95 \%$ of all ultraphytoplankton cells in surface waters and they were also numerically dominant at the nitracline PE maximum (Figs, 4 and 5). At the base of the euphotic layer total numbers of photoautotrophs were low, but numbers of algae increased (Fig. 5) and they became a significant component of deepest ultraphytoplankton assemblages (Fig. 4). In contrast, bacterial abundance remained relatively high throughout the euphotic layer (note abscissa scales on Fig. 5).

The distribution of the 2 ultraphytoplankton components with light depth (Fig. 5) was also reflected in their relative contributions to Chl concentrations (Fig. 7). That is, Synechococcus spp. were generally the major contributors to the standing crop of $\mathrm{Chl}$ in the surface isothermal layer, while ultraplankton algae provided most at the Chl maximum and $0.5 \%$ light level (Fig. 7). At both stations, ultraplankton algae made a significantly greater contribution to integrated water-column Chl than Synechococcus spp., while $>5 \mu \mathrm{m}$ algae provided only a minimal part of the total concentration (Fig. 7).

We further characterized the Synechococcus components of the ultraplankton by examining their relative abundance in 3 size classes and by using immunofluorescence assays to enumerate 2 different Synechococcus serogroups in 0.6 to 1 and 1 to $5 \mu \mathrm{m}$ fractions. At both stations, the majority of Synechococcus cells were consistently found in the 0.6 to 1 um fraction, while the minority were in the smallest 0.2 to $0.6 \mu \mathrm{m}$ fraction (Fig. 8). However, the mean size of the population increased with increasing depth (Fig. 8). Immunofluorescent labelling of populations by antiserum directed against the Sargasso Sea isolate WH7803 showed that there was no apparent difference in the labelling patterns of Synechococcus cells in either 0.6 to $1 \mu \mathrm{m}$ or 1 to $5 \mu \mathrm{m}$ size-fractions (Fig. 9). Similar results were obtained with antiserum directed against the coastal Synechococcus isolate WH8016 at Stn 2 (data not shown). Furthermore, very weak reactions and low percentage labelling at most depths suggests that the oceanic WH7803 serogroup was not a dominant component of populations at either station (Fig. 9) and 75 to $93 \%$ of all Synechococcus cells at any depth were not labelled by either antiserum at Stn 2 .

\section{Temporal changes at Stn 1}

In addition to the PE maximum located at the nitracline, an additional $\mathrm{PE}$ maximum was also found within the isothermal layer at $10 \mathrm{~m}$ on 20 July at Stn 1 (Fig. 3). It was evident that both PE maxima represented depths of relatively high total primary productivity (Table 2) and cellular photosynthesis (data not shown), with phytoplankton assemblages dominated by Synechococcus spp. (89 to $97 \%$ of all $<5 \mu \mathrm{m}$ cells) that were highly enriched in PE (28 and $40 \mathrm{fg} P E$ cell $^{-1}$ at 64 and $6 \% \mathrm{I}_{0}$, respectively; Fig. 6). The $10 \mathrm{~m} \mathrm{PE} \mathrm{maximum} \mathrm{did} \mathrm{not}$ persist. Indeed, the water-column at Stn 1 was in transition throughout our $5 \mathrm{~d}$ monitoring period: there was a $1 \mathrm{C}^{\circ}$ warming above the thermocline between 20 and 26 July (Fig. 2). Advective forces did not appear to be involved, since the surface warming could be solely accounted for by local heating (incident solar radiation was $13 \times 10^{7} \mathrm{~J} \mathrm{~m}^{-2}$ during the period in which $5.3 \times 10^{7}$ $\mathrm{J} \mathrm{m}^{-2}$ of heating occurred). During the same period,
Fig. 6. Pigment concentrations in Synechococcus cells as a function of light depth on 20 July at Stn $12(+--++)$, and 2 August at Stn $2(\bullet-\bullet)$. Left graph represents cellular $\mathrm{Chl}$ content in the 0.6 to $1 \mu \mathrm{m}$ fraction, which could be considered as a pure Synechococcus population $(>95 \%$ of all phytoplankton cells) except for the bottom 2 depths. Right graph shows PE content of all Synechococcus cells $>0.6 \mu \mathrm{m}$
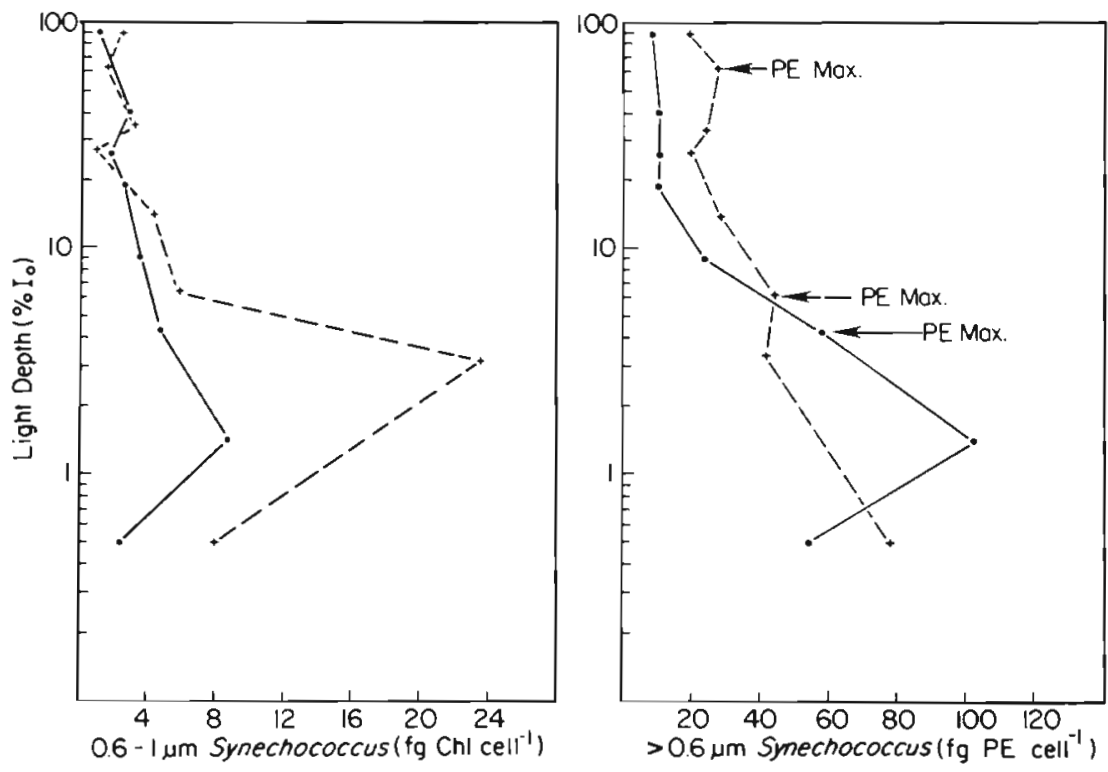

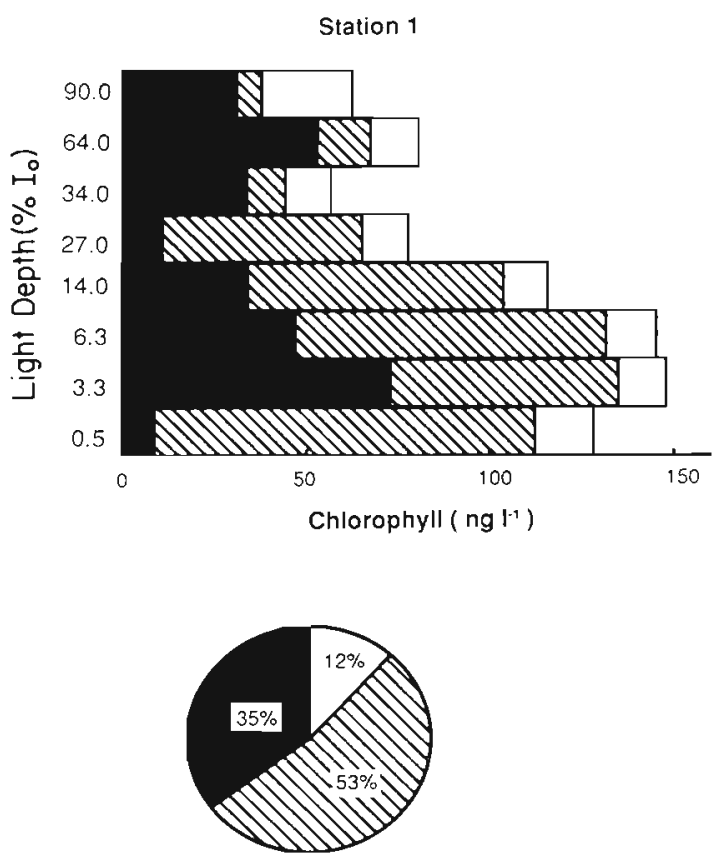

Total: $14.7 \mathrm{mg} \mathrm{Chl} \mathrm{a} \mathrm{m}{ }^{2}$
Station 2
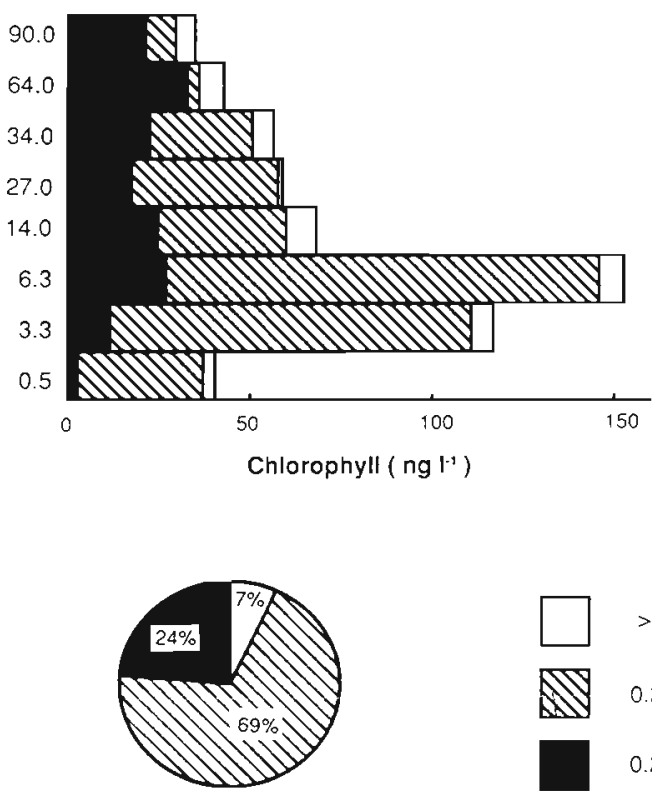

$>5 \mu m$ algae

$0.2-5.0 \mu \mathrm{m}$ algae

$0.2-5.0 \mu \mathrm{m}$ Synechococcus

Fig. 7. Contributions of $>5 \mu \mathrm{m}$ algae, ultraplankton algae and Synechococcus spp. to Chl concentrations at specific light depths and to the total integrated water-column Chl at Stn 1 on 20 July and at Stn 2 on 2 August. Concentrations in $>5 \mu m$ algal assemblages were determined directly from size-fractioned data, while concentrations in ultraplankton algal communities and Synechococcus populations were calculated

there was a 4 -fold reduction in nitrate concentrations in the upper $25 \mathrm{~m}$ of the water-column $\left(417 \mu \mathrm{mol} \mathrm{NO}_{3}\right.$ $\mathrm{m}^{-2}$ ) and a Synechococcus bloom occurred. Elevated surface nitrate concentrations on 20 July (Fig. 3) were accompanied by high rates of primary production (Table 2), and were followed $48 \mathrm{~h}$ later by a $50 \%$ net increase in Synechococcus cell numbers (Fig. 4). In contrast, numbers of ultraplankton algae remained the same (Fig. 4). Numbers of Synechococcus spp. subsequently declined from a maximum of $17 \times 10^{6}$ cells $^{-1}$ in surface waters $(2$ to $5 \mathrm{~m})$ to $8 \times 10^{6}$ cells $1^{-1}$ by 25 July. Between 20 and 25 July, the 4 -fold reduction in nitrate concentrations in the upper $25 \mathrm{~m}$ of the watercolumn was accompanied by a 5 -fold decrease in PE concentrations, but only a 2 -fold decrease in Chl concentrations (Fig. 3). The reduction in PE concentrations in surface waters was not solely due to the decrease in Synechococcus cell numbers, since the mean cellular $\mathrm{PE}$ content also declined from 24 to $6 \mathrm{fg} \mathrm{PE} \mathrm{cell}^{-1}$ during the same period.

Temporal changes in Synechococcus abundance were not confined to the surface isothermal layer, since cell numbers doubled between 20 and 22 July at the Chl maximum (Fig. 4). After 22 July, Synechococcus cell numbers declined and the Chl maximum became deeper and more sharply defined. By 25 July, PE concentrations below the $7 \%$ light level were also 2 to 4 times lower than those at a corresponding depth $5 \mathrm{~d}$ earlier (Fig. 3).

\section{Depth-dependent differences between stations}

Despite the temporal variability at Stn 1, differences were still evident in phytoplankton distributions between the 2 stations. Comparing time course data sets obtained over $5 \mathrm{~d}$ at each station, we found that Synechococcus spp. were consistently more abundant within the surface isothermal layer, the PE/nitracline maximum and the ChI maximum at Stn 1 (Fig. 4). The higher phytoplankton abundance presumably explains why the attenuation coefficient for the water-column was higher at Stn 1 (Fig. 2). While numbers of ultraplankton algae increased below the nitracline at both stations, they were nearly twice as abundant at the Chl maximum and $0.5 \%$ light level of $\operatorname{Stn} 2$, where they represented 54 to $75 \%$ of all autofluorescent ultraplankton $(<5 \mu \mathrm{m}$ ) cells (Fig. 4). Station differences in the relative abundance of the 2 ultraphytoplankton components were also reflected in estimates of their separate contributions to the standing crop of Chl. Fig. 7 shows that Synechococcus spp. made a greater contribution to integrated water-column Chl at Stn 1, compared with that at Stn 2 , while the converse was true for ultraplankton algae. 
Fig. 8. Distribution of Synechococcus spp. in 3 size fractions (black: 0.2 to $0.6 \mu \mathrm{m}$; hatched: 0.6 to $1 \mu \mathrm{m}$; stippled: 1 to $5 \mu \mathrm{m}$ ), at 4 locations in the water-column over the course of the monitoring periods at Stn 1 (left graph) and Stn 2 (right graph)
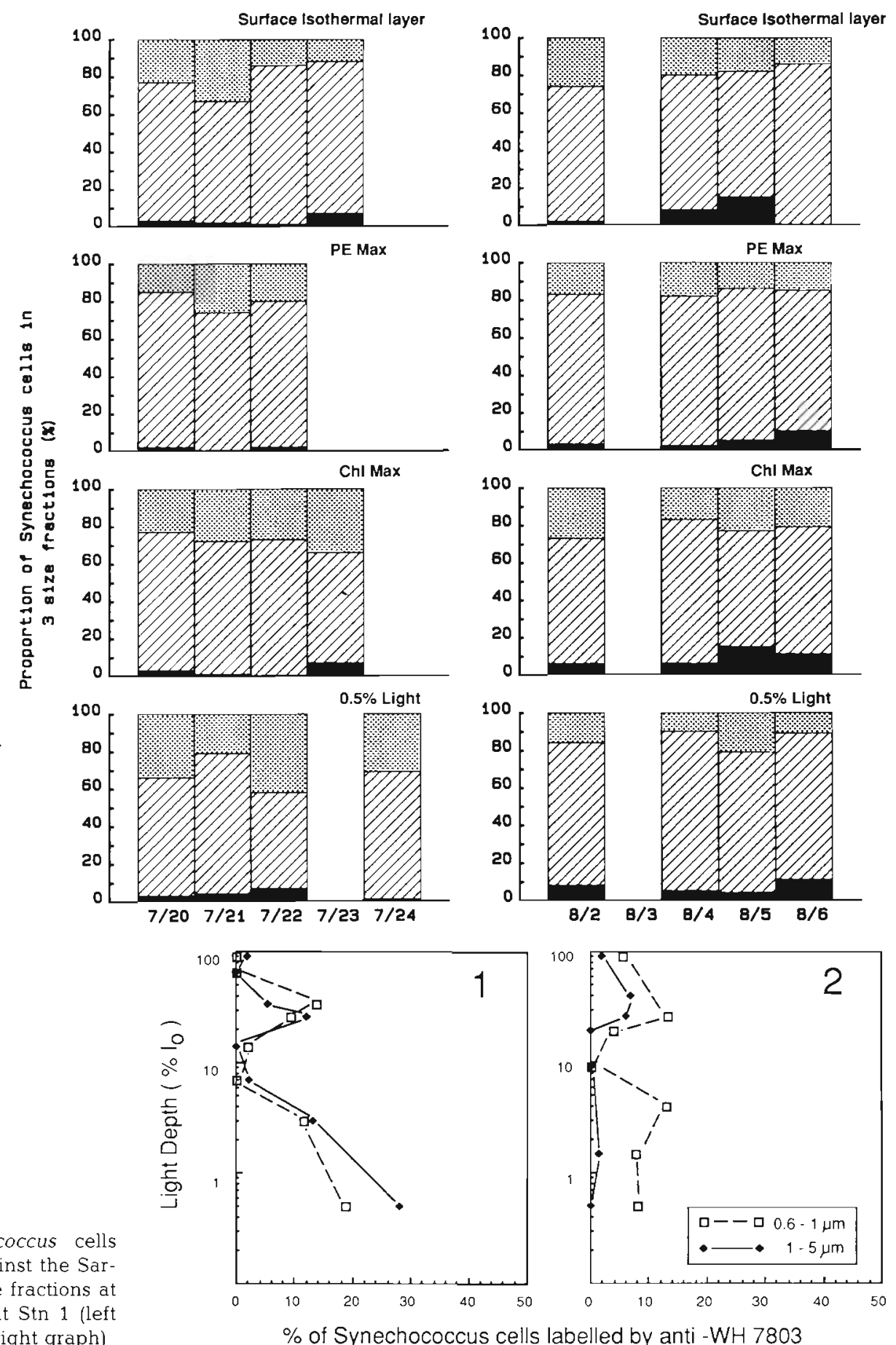

Fig. 9. Percentage of Synechococcus cells labelled by antiserum directed against the Sargasso Sea isolate WH7803 in 2 size fractions at different light depths on 20 July at Stn 1 (left graph) and on 2 August at Stn 2 (right graph)
Not only were ultraplankton algae more abundant below the $10 \%$ light level at Stn 2 (Fig. 5), but there were proportionately more smaller cells (Fig. 10). There was a reduction in mean cell size below the nitracline and 79 to $89 \%$ of the algae at the base of the photic layer at Stn 2 were in the picoplankton fraction (passing through 1 um Nuclepore filters).

\section{DISCUSSION}

Open ocean regions constitute three-quarters of the world's oceans, yet the rates of oceanic carbon and nitrogen cycling are uncertain by one order of magnitude (e.g. Eppley 1980, Jenkins \& Goldman 1985). Some of the discrepancies between data sets may be 
due to the time scales over which observations were made (Kerr 1986). It has been suggested that in nitrogen-limited ocean systems, episodic increases in nitrate concentrations may support a significant fraction of the total annual primary production (Platt \& Harrison 1985). Nitrate pulses could be easily missed by occasional sampling strategies. Results from Stn 1 show that transient nanomolar increases in surface nitrate concentrations do indeed occur in stratified oceanic waters over a few days (Fig. 3), and can rapidly enhance phytoplankton production over similar time scales (Fig. 4). The temporal sequence of phytoplankton properties describing the nitratedependent Synechococcus bloom in the surface isothermal layer at Stn 1 is provided in more detail in a note by Glover et al. (1988). The change in nitrate concentrations between 20 and 25 July was stoichiometrically consistent with the subsequent cellular production of Synechococcus carbon and measured grazing rates (Glover et al. 1988). Data suggested that Synechococcus spp. alone responded to the enhanced supply of nitrate, which may have been due to faster uptake kinetics conferred by their high surface area/volume ratio (Raven 1986), but may also reflect a capacity to rapidly translate increased cellular nitrogen into growth and cell division (Collos 1986).

The source of the initially high nitrate concentrations in the surface isothermal layer is a matter of conjecture. A numerical study showed that wind-surface current interactions can affect both the instantaneous nutrient distribution and the mean level of its transport through the thermocline (Klein \& Coste 1984), and there were major storms in the Sargasso Sea between 2 and 4 July and between 9 and 11 July (log of RV 'Cape Hatteras' Cruise $\mathrm{CH}-12-86)$. These events were apparently sufficient to cause mixing at Stn 1 , which resulted in a surface isothermal layer that was $1 \mathrm{C}^{\circ}$ cooler than typical seasonal values, and temperatures of $>26^{\circ} \mathrm{C}$ were observed only after 23 July (Fig. 2). Using the chemiluminescent nitrate method, Eppley \& Renger (1988) also reported nanomolar increases in surface layer nitrate concen-

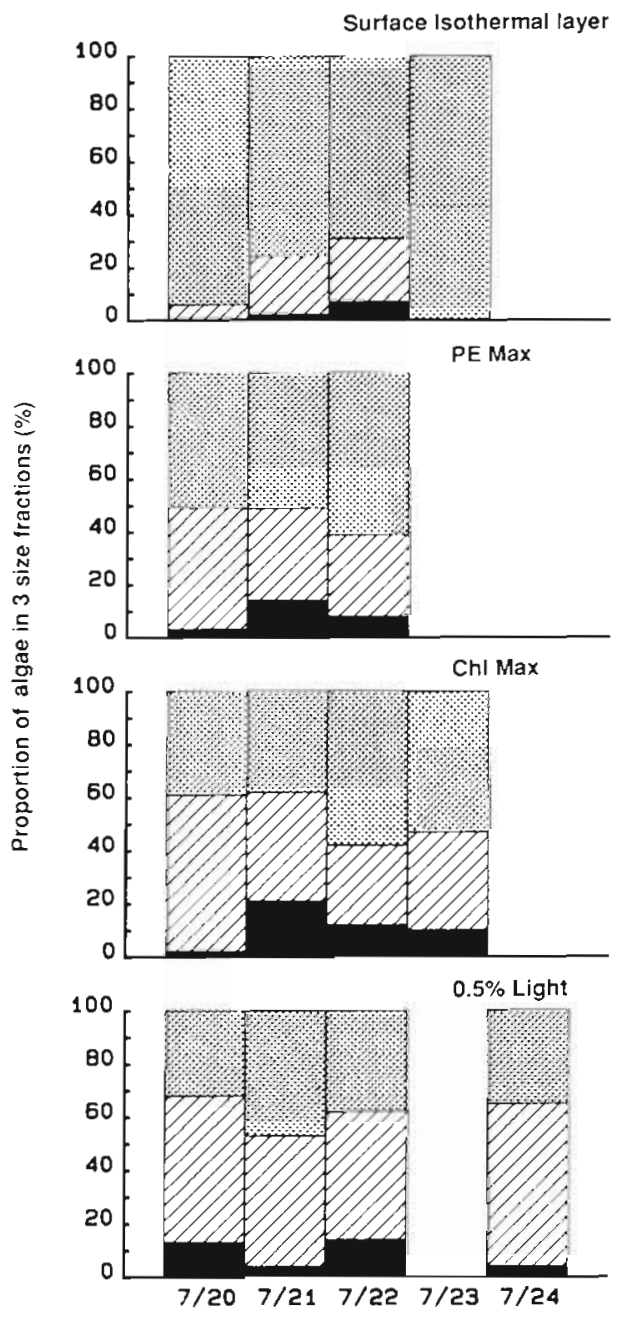

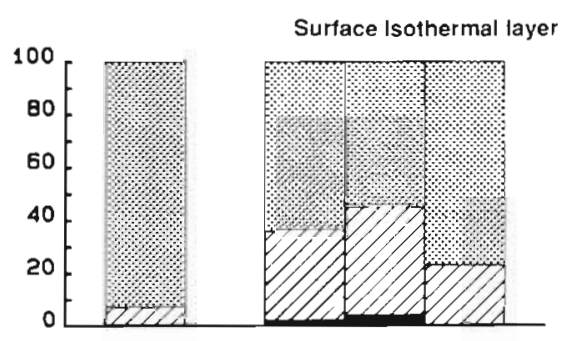
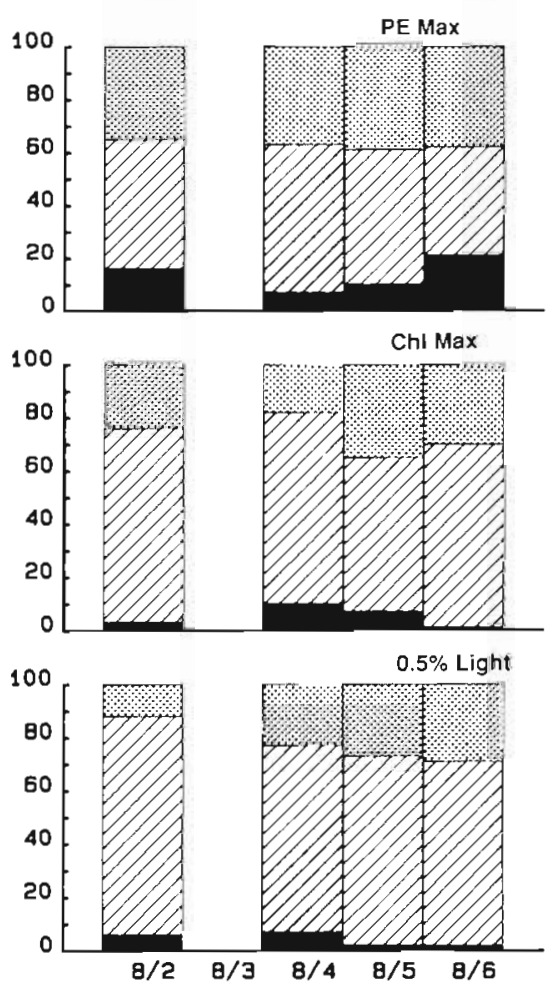

Fig. 10. Distribution of ultraplankton algae in 3 size fractions (black.

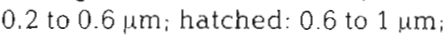
stippled: 1 to $5 \mu \mathrm{m}\}$, at 4 locations in the water-column over the course of the monitoring periods at Stn 1 (left graph) and Stn 2 (right graph) 
trations following a small wind event in stratified California waters

It is well established that oceanic Synechococcus spp. use PE as their primary light-harvesting pigment (see review by Glover 1985), but the ability of marine Synechococcus spp. to use some of their PE pigment as a nitrogen reserve has recently been debated (Barlow \& Alberte 1985, Wyman et al. 1985, Glibert et al. 1986 Yeh et al. 1986 vs Wyman et al. 1986, Kana \& Glibert 1987). Data presented here support the additional role of $\mathrm{PE}$ in nitrogen storage: first, the 4 -fold decline in surface layer nitrate concentrations between 20 and 25 July at Stn 1 (Fig, 3) was accompanied by a 4 -fold decrease in PE concentrations within Synechococcus cells (24 to $6 \mathrm{fg}^{\mathrm{PE}}$ cell ${ }^{-1}$ ). Secondly, in the surface isothermal layer there was a 2 -fold decline in $\mathrm{PE} / \mathrm{Chl}$ ratios in the total Synechococcus population $(>0.6 \mu \mathrm{m})$ during this period (Glover et al. 1988). This change in the pigment ratio of Synechococcus cells is unlikely to have resulted from photoadaptation, since populations were at light-saturating depths for growth 90 to $34 \% \mathrm{I}_{0}$ (Glover et al. 1987), with $\mathrm{I}_{\mathrm{k}}$ values (Table 2) and Chl contents (Fig. 6) that are typical of high-light adapted cells (Glibert et al. 1986, Prézelin et al. 1986, Glover et al. 1987). Thus, our data suggest a causal relationship between initially high nitrate concentration and high cellular PE content.

Our data provide the first measurements of maxima in PE concentrations per liter in the Sargasso Sea by looking at glycerol-uncoupled PE fluorescence yield. Without these measurements, we would not have had a sampling rationale for locating sites of PE-rich Synechococcus cells with high photosynthetic activity, nor would we have been able to determine how the PE content of Synechococcus cells varied with depthdependent changes in light and nutrient availability. The deep PE maxima we identified were associated with the nitracline (Fig. 3) and resulted from the increased PE content of Synechococcus cells and not from an increase in their abundance (compare Figs. 5 and 6 ). These data substantiate earlier flow cytometry results of an increase in PE fluorescence intensity per cell with increasing depth (Olson et al. 1985). While Synechococcus cells had a relatively high PE content at deep PE maxima (Fig. 6), $I_{k}$ values attested to the fact that communities would not be limited by the in situ irradiance during most of the day and primary productivity was relatively high (Table 2). Thus, these Synechococcus populations appeared to effectively use the increased nitrogen flux at the nitracline for $\mathrm{PE}$ synthesis, thereby enhancing absorption of the available blue radiation and resulting in relatively high cellular rates of photosynthesis. Furthermore, these Synechococcus populations were not dominated by the WH7803 serotype (Fig. 9), but contained cells whose
PE fluorescence emission characteristics were typical of clone WH8103 (Campbell \& Iturriaga 1988), whose higher complement of phycourobilin to phycoerythrobilin chromophores enhances absorption at shorter blue wavelengths of $490 \mathrm{~nm}$ (Ong et al. 1984). Using flow cytometry single cell analysis, Olson et al. (1988) reported that the high phycourobilin pigment type invariably dominated oceanic Synechococcus populations from other regions

Comparing our results with data sets from several other investigations (Glover et al. 1985, Murphy \& Haugen 1985, Waterbury et al. 1986, Campbell \& Carpenter 1987, Iturriaga \& Marra 1988), it appears that there is considerable temporal and spatial variability in the abundance and composition of Sargasso Sea Synechococcus populations: Fig. 3 demonstrates the variability that we observed in PE concentrations per liter above the thermoclines $\left(>30 \% \mathrm{I}_{0}\right)$ at the 2 stations. These differences were not solely related to Synechococcus cellular abundance. The $10 \mathrm{~m}$ transient $\mathrm{PE}$ maximum at $\mathrm{Stn} 1$ was due to a Synechococcus population with increased pigment content (28 fg PE cell $^{-1}$ ) and relatively high photosynthetic activity (Table 2). These results suggest that this $10 \mathrm{~m}$ community was actively growing and that the isothermal layer was not necessarily a homogenous mixed layer at this time. Synechococcus cell numbers at Stn 1 were always higher in surface waters, the PE maximum and the Chl maximum, compared with those at Stn 2 (Fig. 4). This was reflected in their contribution to the standing crop of Chl (Fig. 7) and the different attenuation coefficients of the 2 water-columns (Fig. 2). The significance of Synechococcus spp. at the Chl maximum of Stn 1 was shown by their enhanced contribution to the Chl concentration (Fig. 7) and a doubling in their abundance (Fig. 4) over the $3 \mathrm{~d}$ in which the temporal changes occurred in the upper $25 \mathrm{~m}$.

Reported abundances of Synechococcus spp. in July and August in Sargasso surface waters range from 3 to $17 \times 10^{6}$ cells $1^{-1}$ (Glover et al. 1985, Murphy \& Haugen 1985, Waterbury et al. 1986) with the maximum value being found on 22 July at Stn 1 (Fig. 4). In stratified oceanic regions, greatest numbers of Synechococcus spp. are often in surface waters (Waterbury et al. 1986; Fig. 4), but a maximum has been found at much lower light levels, where the nutrient supply is increased (Glover et al. 1985, Murphy \& Haugen 1985, Waterbury et al. 1986, Campbell \& Carpenter 1987). In April 1985, Iturriaga \& Marra (1988) recorded maximum abundances of Synechococcus cells in surface waters north of the Subtropical Atlantic Convergence, while maximum numbers occurred near the bottom of the euphotic zone south of the front $\left(24^{\circ} \mathrm{N}\right)$. Variability also occurs in the serogroup composition of Synechococcus spp. 
populations in the Sargasso Sea (Campbell \& Carpenter 1987).

While Synechococcus spp. were the dominant component of ultraphytoplankton communities above $10 \%$ $I_{0}$, Chl-fluorescing algae became the dominant component of ultraplankton biomass at the bottom of the euphotic zone, particularly at Stn 2 (Figs. 4, 5 and 7). Data from Stn 2 (Figs. 4 and 5) confirm previous light depth distribution patterns in the composition of ultraplankton in stratified oceanic systems (Furuya \& Marumo 1983, Takahashi \& Bienfang 1983, Takahashi \& Hori 1984, Glover et al. 1985, Murphy \& Haugen 1985, Gieskes \& Kraay 1986, Trees et al. 1986).

At both stations there was a change in the cell size distribution of ultraplankton algal communities with increasing depth (Fig. 10). The majority of algae were in the 1 to $5 \mathrm{um}$ fraction above the nitracline, while with increasing depth below it, there were proportionately more smaller cells. This was particularly evident at Stn 2 , where 79 to $89 \%$ of algal cells at the bottom of the euphotic layer were in the $<1 \mu \mathrm{m}$ picoplankton fraction (Fig. 10). Since sinking rates of these small forms is negligible (Takahashi \& Bienfang 1983), increases in the abundance of picoplankton algae at depth (Fig. 5) may be attributed to in situ growth, and their ecological success at low intensities of blue-violet light may be due, in part, to their complement of blue-violet absorbing accessory pigments (Brown 1985, Wood 1985, Glover et al. 1987) and a relatively high specific absorption coefficient conferred by their small cell volume (Kirk 1986). While the high phycourobilin to phycoerythrobilin chromophore complement in the PE of Synechococcus populations would enhance their ability to use the blue light available at the nitracline $\mathrm{PE}$ maximum, the pigmentation of oceanic picoplankton algae gives them a competitive advantage deeper in the water-column. It should be noted however, that while the numerical abundance of ultraplankton algae was greatest in the blue-violet light regime found at $0.5 \% \mathrm{I}_{0}$ at both stations (Fig. 5), low $\mathrm{I}_{\mathrm{k}}$ values and photosynthetic rates (Table 2) suggested that even though these communities were shade-adapted, photosynthesis was light-limited.

The numerical dominance of Synechococcus spp. in surface waters (Fig. 4) cannot be explained in terms of irradiance, since at saturating intensities of white light and nutrient sufficient conditions, clones of oceanic Synechococcus and ultraplankton algae have comparable growth rates (Glover et al. 1987). Consequently, the varying depth distributions of the 2 ultraplankton groups can be partially explained in terms of light intensity and quality, but it seems likely that differences in nutrient uptake kinetics could also be a factor.

In conclusion, comparisons between previous data sets and those presented here for summer Sargasso Sea communities suggest that there is a considerable degree of temporal and geographic variability in the abundance and composition of ultra- and pico-phytoplankton at comparable locations within the watercolumn.

Acknowledgements. We thank W. Connelly, A. Langeley, H. A. Matlick, N. Nelson, O. Schofield, A. E. Smith, D. Steinberg, C. Garside, A. Steiner, B. Ver Hoven, G. Campbell and the RV 'Endeavor' crew for assistance with sample collection and measurements. Thanks are also extended to J. Rollins, K. Knowlton and H. A. Matlick for graphics and P. Colby and M. Hernandez-Davis for manuscript preparation. This research was supported by N.S.F. grants OCE8521170, OCE8515738 and OCE8614116.

\section{LITERATURE CITED}

Barlow, R. G., Alberte, R. S. (1985). Photosynthetic characteristics of phycoerythrin-containing marine Synechococcus spp. I. Responses to growth photon flux density. Mar. Biol. 86: 63-74

Brown, J. S. (1985). Three photosynthetic antenna porphyrins in a primitive green alga. Biochim. Biophys. Acta 807: $143-146$

Campbell, L., Carpenter, E. J. (1987). Characterization of phycoerythrin-containing Synechococcus spp. populations by immunofluorescence. J. Plankton Res. 9: 1167-1181

CampbelI, L., Iturriaga, R. (1988). Identification of Synechococcus spp. in the Sargasso Sea by immunofuorescence and fluorescence excitation spectroscopy performed on individual cells. Limnol. Oceanogr. (in press)

Collos, Y. (1986). Time-lag algal growth dynamics: biological constraints on primary production in aquatic environments. Mar. Ecol. Prog. Ser. 33: 193-206

Eppley, R. W. (1980). Estimating phytoplankton growth rates in the central oligotrophic oceans. In: Falkowski, P. G. (ed.) Primary productivity in the sea. Brookhaven Symposia in Biology, Vol. 31. Plenum Press, New York, p. 231-242

Eppley, R. W., Renger, E. H. (1988). Nanomolar increases in surface layer nitrate concentration following a small wind event. EOS 68: Abstract 12D-11

Fitzwater, S. E., Knauer, G. A., Martin, J. H. (1982). Metal contamination and its effect on primary production measurements. Limnol. Oceanogr. 27: 544-551

Fogg, G. E. (1986). Picoplankton. Proc. R. Soc. Lond. B 228: $1-30$

Furuya, K., Marumo, R. (1983). The structure of the phytoplankton community in the subsurface chlorophyll maximum in the western North Pacific. J. Plankton Res. 5: 393-406

Garside, C. (1982). A chemiluminescent technique for the determination of nanomolar concentrations of nitrate, nitrate and nitrite, or nitrite aione in seawater. Mar. Chem. 11: $159-167$

Gieskes, W W. C., Kraay, G. W. (1986). Floristic and physiological differences between the shallow and deep nanophtoplankton community in the euphotic zone of the open tropical Atlantic revealed by HPLC analysis of pigments. Mar. Biol. 91 567-576

Glibert, P. M., Kana, T M., Olson, R. J., Kirchman, D. L., Alberte, R. S. (1986). Clonal comparisons of growth and photosynthetic responses to nitrogen availability in marine Synechococcus spp. J. exp. mar. Biol. Ecol. 101: 199-208 
Glover, H. E. (1985). The physiology and ecology of the marine cyanobacterial genus Synechococcus. In: Jannasch, H. W., Williams, P. J. LeB. (eds.) Advances in aquatic microbiology. Academic Press, London, p. 49-107

Glover, H. E., Smith, A. E., Shapiro, L. P. (1985). Diurnal variations in photosynthetic rates: comparisons of ultraphytoplankton with a larger size fraction. J. Plankton Res. 7: 519-535

Glover, H. E., Campbell, L., Prézelin, B. B. (1986). Contribution of Synechococcus to size-fractioned primary productivity in three water masses in the Northwest Atlantic Ocean. Mar. Biol. 91 193-203

Glover, H. E., Keller, M. D., Spinrad, R. W. (1987). The effects of light quality and intensity on photosynthesis and growth of marine eukaryotic and prokaryotic phytoplankton clones. J. exp. mar. Biol. Ecol. 105: 137-159

Glover, H. E., Prézelin, B. B., Campbell, L., Wyman, M., Garside, C. (1988). Observations of a nitrate-dependent Synechococcus bloom in surface Sargasso Sea water. Nature, Lond. 331. 161-163

Hobbie, J. E., Daley, R. J., Jasper, S. (1977). Use of Nuclepore filters for counting bacteria by fluorescence microscopy. A.ppl. environ, Microbiol. 33: 1225-1228

Iturriaga, R., Marra, J. (1988). Temporal and spatial variability of chroococcoid cyanobacteria, Synechococcus spp., specific growth rates and their contribution to primary production in the Sargasso Sea. Mar. Ecol. Prog. Ser 44: $175-181$

Jenkins, W. J., Goldman, J. C. (1985). Seasonal oxygen cycling and primary production in the Sargasso Sea. J. mar Res. 43: 465-491

Kana, T M., Glibert, P. M. (1987). Effect of irradiances up to $2000 \mu \mathrm{E} \mathrm{m}^{-2} \mathrm{~s}^{-1}$ on marine Synechococcus WH7803 - I. Growth, pigmentation and cell composition. Deep Sea Res. $34: 479-495$

Kerr, R. A. (1986). The ocean's deserts are blooming. Science 232: 1345

Kirk, J. T O. (1986). Optical properties of picoplankton suspensions. In: Platt, T., Li, W. K. W (eds.) Photosynthetic picoplankton. Can. Bull. Fish. Aquat. Sci. 214: 501-520

Klein, P., Coste, B. (1984). Effects of wind-stress variability on nutrient transport into the mixed layer. Deep Sea Res. 31: 21-37

Laws, E. A., DiTullio, G. R., Redalje, D. G. (1987), High phytoplankton growth and production rates in the North Pacific subtropical gyre. Limnol. Oceanogr. 32: 905-918

Marra, J., Heinemann, K. R. (1987). Primary production in the North Pacific Central Gyre: some measurements based on ${ }^{14} \mathrm{C}$. Deep Sea Res. 34: 1821-1829

Murphy, L. S., Haugen, E. M. (1985). The distribution and abundance of phototrophic ultraplankton in the North Atlantic. Limnol. Oceanogr. 30:47-58

Olson, R. J., Vaulot, D., Chisholm, S. W. (1985). Marine phytoplankton distributions measured using shipboard flow cytometry. Deep Sea Res. 32: 1273-1280

Olson, R. J., Chisholm, S. W., Zettler, E. R., Ambrust, E. V (1988). Analysis of Synechococcus pigment types in the sea using single and dual beam flow cytometry. Deep Sea Res. 34: 425-440

Ong, L. J., Glazer, A. N., Waterbury, J. B. (1984). An unusual phycoerythrin from a marine cyanobacterium. Science 224: $80-83$

Platt, T., Harrison, W. G. (1985). Biogenic fluxes of carbon and oxygen in the ocean. Nature, Lond. 318: 55-58

Platt, T., Li, W K.W (1986). Photosynthetic picoplankton. Can. Bull. Fish. Aquat. Sci. 214: 1-583

Prézelin, B. B., Bidigare, R. R., Matlick, H. A., Putt, M. Verhoven, B. (1987). Diumal patterns of size-fractioned primary productivity across a coastal front. Mar. Biol. 96: $563-574$

Prézelin, B. B., Putt, M., Glover, H. E. (1986). Diurnal patterns in photosynthetic capacity and depth-dependent photosynthesis-irradiance relationships in Synechococcus spp. and larger phytoplankton in three water masses in the Northwest Atlantic Ocean. Mar. Biol. 91: 205-217

Raven, J. A. (1986). Physiological consequences of extremely small size for autotrophic organisms in the sea. In: Platt, $\mathrm{T}$. Li, W. K. W. (eds.) Photosynthetic picoplankton. Can. Bull. Fish. Aquat. Sci. 214: 1-70

Stockner, J. G., Antia, N. J. (1986). Algal picoplankton from marine and freshwater ecosystems: a multidisciplinary perspective. Can. J. Fish. Aquat. Sci. 43: 2472-2503

Strickland, J. D. H., Parsons, T R. (1972). A practical handbook of seawater analysis, 2nd edn. Bull. Fish. Res. Bd Can. 167

Takahashi, M., Bienfang, P. K. (1983). Size structure of phytoplankton biomass and photosynthesis in subtropical and tropical Hawaiian waters. Mar Biol. 76: 203-211

Takahashi, M. Hori, T (1984). Abundance of picophytoplankton in the subsurface chlorophyll maximum layer in subtropical and tropical waters. Mar Biol. 79: 177-186

Trees, C. C., Bidigare, R. R., Brooks, J. M. (1986). Distribution of chlorophylls and phaeopigments in the Northwest Atlantic Ocean. J. Plankton Res. 8: 447-458

Waterbury, J. B., Watson, S. W., Valois, F. W., Franks, D. G (1986). Biological and ecological characterization of the marine unicellular cyanobacterium Synechococcus. In: Platt, T., Li, W K. W. (eds.) Photosynthetic picoplankton. Can. Bull. Fish Aquat. Sci 214: 71-120

Wood, A. M. (1985). Adaptation of photosynthetic apparatus of marine ultraphytoplankton to natural light fields. Nature, Lond. 316: 253-255

Wyman, M., Gregory, R. P. F., Carr, N. G. (1985). Novel role for phycoerythrin in a marine cyanobacterium, Synechococcus strain DC-2. Science 230: 818-820

Wyman, M., Gregory, R. P. F., Carr, N. G. (1986). Role of phycoerythrin in marine Synechococcus spp. Science 234 : $1423-1424$

Wyman, M., Carr. N. G. (1988). An in vivo method for the estimation of phycoerythrin concentrations in marine cyanobacteria (Synechococcus spp). Limnol. Oceanogr. (in press)

Yeh, S. W., Ong, L., Glazer, A. N. (1986). Role of phycoerythrin in marine picoplankton Synechococcus spp. Science 234: $1422-1423$ 